\title{
Our Clinical Experiences in Patients with Nutcracker Syndrome
}

Hatice Sonay Yalçın Cömert $\odot$
Elif Bahat Özdoğan $\odot$
Sema Tural Bozoğlu $\odot$
Gül Şalcı $\odot$
Haluk Sarıhan $\odot$
Mustafa İmamoğlu $\odot$

\author{
Nutcracker Sendromlu Hastalarda Klinik \\ Deneyimlerimiz
}

\section{ABSTRACT}

Objective: Nutcracker syndrome (NCS) is a rare condition caused by the compression of the left renal vein between the abdominal aorta and superior mesenteric artery. The purpose of the study was to evaluate our management of NCS.

Methods: Patients were retrospectively reviewed and sex, age, main symptoms at application, physical examination, radiological findings, laboratory examinations, and treatment were recorded.

Results: 23 patients (16 girls, 7 boys; age range, 5 to 16) diagnosed with NCS. Microhematuria was detected with 14 (60.8\%) patients before diagnosis. And four of 9 (39.1\%) were determined after diagnosis. Microhematuria was not detected in 5 (21.7\%) of the patients. All patients (100\%) had orthostatic proteinuria. 17 (73.9\%) patients had mild, $3(13.0 \%)$ patients had moderate and $3(13.0 \%)$ had severe proteinuria. The mean diameter of the left renal vein (LRV) at the aortomesenteric (AM) portions and the hilar were $1.69 \mathrm{~mm} \pm 0.70$ and $8.01 \mathrm{~mm} \pm 2.27$. The mean angle between the superior mesenteric artery and $L R V$ was $25.26 \pm \pm 7.98$.

Conclusion: In the case of especially colic flank pain, hematuria, and proteinuria NCS should keep in mind in the differential diagnosis. Surgical management may supply more enough clinic improvement when the patient has a response to medical therapy.

Keywords: Nutcracker syndrome, renal colic, hematuria, proteinuria

öz

Amaç: Nutcracker sendromu (NCS), abdominal aorto ve superiar mezenterik arter arasındaki sol renal venin sıkışmasından kaynaklanan nadir bir durumdur. Çalışmanın amacı, NCS tanısı konulan hastalara genel yaklaşımımızı değerlendirmektir.

Yöntem: Hastalar retrospektif olarak incelendi ve cinsiyet, yaş, uygulamadaki ana semptomlar, fizik muayene, radyolojik bulgular, laboratuvar muayeneleri ve tedavi kaydedildi.

Bulgular: 23 hasta (16 kız, 7 erkek; yaş aralığı, 5-16) NKS tanısı aldı. Tanıdan önce 14 hastada $(\% 60,8)$ mikrohematüri saptandı. Teşhisten 9 taneden dördünde $(\% 39,1)$ tanı aldıktan sonra belirlendi. Hastaların 5 'inde $(\% 21,7)$ mikrohematüri saptanmadı. Tüm hastalarda (\%100) ortostatik proteinüri vardı. $17(\% 73,9)$ hastada hafif, $3(\% 13,0)$ hastada orta, $3(\% 13,0)$ hastada ciddi proteinüri vardı. Aortmezenterik (AM) ve hilerde sol renal venin ( $L R V$ ) ortalama çapı $1.69 \mathrm{~mm} \pm 0,70$ ve $8,01 \mathrm{~mm} \pm 2,27$ idi. Üst mezenterik arter ve $L R V$

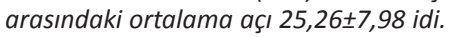

Sonuç: Özellikle kolik yan ağrısı, hematüri ve proteinüri olması durumunda NCS ayırıcı tanıda akılda tutulmalıdır. Cerrahi tedavi, hasta tıbbi tedaviye yanıt verdiğinde daha fazla klinik iyileşme sağlayabilir.

Anahtar kelimeler: Nutcracker sendromu, renal kolik, hematüri, proteinüri
Received: 15.04 .2020

Accepted: 04.08 .2020

Published Online: 30.04 .2021

Cite as: Yalcin Comert HS, Bahat Özdoğan E, Tural Bozoğlu S, Şalcı G, Sarıhan H, İmamoğlu M. Our Clinical Experiences In Patients With Nutcracker Syndrome. İzmir Dr. Behçet Uz Çocuk Hast. Dergisi. 2021;11(1):9-14.

Hatice Sonay Yalçın Cömert Karadeniz Teknik Üniversitesi Tıp Fakültesi, Çocuk Cerrahisi Anabilim Dalı, Trabzon, Türkiye sonayyalcin@hotmail.com ORCID: 0000-0002-5281-4933

S. Tural Bozoğlu 0000-0002-9762-5896 G. Şalcı 0000-0001-9929-8369

H. Sarıhan 0000-0002-0991-8235

M. İmamoğlu 0000-0001-8267-9755 Karadeniz Teknik Üniversitesi Tıp Fakültesi, Çocuk Cerrahisi Anabilim Dalı, Trabzon, Türkiye

E. Bahat Özdoğan 0000-0002-9785-8067 Karadeniz Teknik Üniversitesi Tıp Fakültesi, Çocuk Nefrolojisi Anabilim Dalı, Trabzon, Türkiye

Our study has been presented orally in 10. National Pediatric Urology Congress, $16^{\text {th }}-19^{\text {th }}$ May, 2019, Samsun, Turkey 


\section{INTRODUCTION}

Nutcracker syndrome (NCS) is a rare condition caused by the compression of the left renal vein (LRV) between the abdominal aorta and superior mesenteric artery (SMA). Nutcracker Phenomenon (NP) is an asymptomatic finding of LRV squeeze, however, NCS is a complex of clinical signs and symptoms differently from NP ${ }^{(1)}$. The syndrome was first defined anatomically by Grant in 1937 as: "the left renal vein, as it lies between the aorta and superior mesenteric artery, resembles a nut between the jaws of a nutcracker" (2). In the etiology of the disease, rapid growth in the puberty period is accused of maturation of vertebral body and angle between SMA and aorta narrows ${ }^{(2)}$. NCS typically presents with left flank pain, hematuria, orthostatic proteinuria, orthostatic intolerance, and gonadal varices (varicocele or ovarian vein syndrome) (1,3,4). Diagnosis is made by ultrasonography, color Doppler ultrasonography, computed tomography angiography, or magnetic resonance angiography ${ }^{(5-9)}$. The treatment ranges from a conservative approach to open surgery according to the patients' clinic and severity of the disease.

We performed a retrospective review of patients diagnosed with NCS in our institution and aimed to evaluate the clinical characteristics and management of 23 patients with this condition.

\section{MATERIAL and METHOD}

We retrospectively reviewed 23 cases of NCS ( 16 girls, 7 boys; age range, 5 to 16) from 2013 to 2018 at our Pediatric Nephrology and Pediatric Surgery Department in Karadeniz Technical University, Faculty of Medicine. The clinical characteristics of the patients, main symptoms at application, physical examination, radiological findings (renal Doppler ultrasonography, magnetic resonance angiography, computed tomography angiography), laboratory examinations, and clinical management were analyzed retrospectively.

The diagnosis was based on the clinical (colic flank pain), laboratory findings (microhematuria, proteinuria -spot and 24-hour protein excretion- and orthostatic proteinuria), and the findings of renal Doppler ultrasonography, magnetic resonance (MR), and computed tomography (CT) angiographies. All patients have done renal Doppler ultrasonography before and after exercise and measured the diameter of the LRV at the aortomesenteric (AM) portions and the hilar region and the mean angle between the superior mesenteric artery and the LRV. Some patients need also MRI or CT angiographies. Patients with an angle between the superior mesenteric artery and the left renal vein less than $35^{\circ}-40^{\circ}$ were diagnosed with NCS.

Microhematuria was defined as while urine color was normal, the presence of 5/HPF erythrocyte in urine microscopy, and blood reaction positivity in dipstick test. Proteinuria in spot urine was defined as protein/creatinine ratio $(\mathrm{mg} / \mathrm{mg})$ is $0.2-1$ : mild, $1-3,5$ : moderate, $>3,5$ heavy proteinuria. Daily urinary protein excretion in 24-h urine $\left(\mathrm{mg} / \mathrm{m}^{2} / \mathrm{h}\right)$ was defined as 4-10 mild, 10-40 moderate, and $>40$ as severe. Proteinuric patients are evaluated for the presence of orthostatic proteinuria. The patients woke up 2 hours or more at night and discharged their bladder. Urine analysis and spot urine protein and creatinine ratio were examined as soon as they got out of bed in the morning. Proteinuria is negative in the dipstick test and the spot urine protein/creatinine ratio in $\mathrm{mg} / \mathrm{mg}<0.2$ was defined as orthostatic proteinuria.

All patients' urine analysis, renal function tests, electrolytes, complete blood count, and blood pressures were normal. The patients who have other urological disorders were excluded from the study.

\section{Statistical Analysis}

Analyses were performed using the Statistical Package for the Social Sciences 18.0 (SPSS). The characteristics of the patients were determined using descriptive statistics. Parameters compatible with normal distribution were defined as mean \pm standard deviations.

\section{RESULTS}

We retrospectively investigated 23 children who were diagnosed as having NCS from 2013 to 2018 of which 16 (65.6\%) were female and 7 (34.4\%) were male. The mean age of our patients was $12.04 \pm 2.96$ years (range 5 to 16 ). All patients complained of colic left flank pain to the hospital. They all resorted to the emergency and needed a painkiller again and again. 
$14(60.8 \%)$ patients had microhematuria before diagnosis. Four of 9 (39.1\%) patients without microhematuria were determined microhematuria after diagnosis. Microhematuria was not detected in 5 (21.7\%) of the patients.

All patients (100\%) had orthostatic proteinuria. 17 (73.9\%) patients had mild, 3 (13.0\%) patients had moderate and $3(13.0 \%)$ had severe proteinuria.

We successfully obtained renal Doppler ultrasonography before and after exercise and MRI angiographies from LRV at the AM and hilar portion in 22 patients. Only one patient underwent CT angiography after renal Doppler ultrasonography. All patients in our study were diagnosed with anterior NCS. The mean diameter of the LRV at the AM portions and the hilar were $1.69 \mathrm{~mm} \pm 0.70$ and $8.01 \mathrm{~mm} \pm 2.27$. The mean angle between the superior mesenteric artery and the LRV was 25.260 \pm 7.98 ; all

Table 1. Baseline clinical characteristics and left renal vein findings of the study.

\begin{tabular}{|c|c|}
\hline Variables & $\begin{array}{l}\text { Study population } \\
\qquad(n=23)\end{array}$ \\
\hline Age (years) & $12.04 \pm 2.96(5-16)$ \\
\hline Gender, n (\%) & $\begin{array}{c}\text { female, } 16(65.6 \%) \\
\text { male, } 7(34.4 \%)\end{array}$ \\
\hline Clinical findings, $\mathrm{n}(\%)$ & Colic flank pain, 23 (100\%) \\
\hline \multicolumn{2}{|l|}{ Microscopic hematuria, n (\%) } \\
\hline Before diagnosis & $14(60.8 \%)$ \\
\hline After diagnosis & $4(17.3 \%)$ \\
\hline Undetected & $5(21.7 \%)$ \\
\hline Ortostatic proteinuria n (\%) & $23(100 \%)$ \\
\hline Proteinuria & $17(73.9 \%)$ \\
\hline Mild & $3(13.0 \%)$ \\
\hline Moderate & $3(13.0 \%)$ \\
\hline \multicolumn{2}{|l|}{ Severe } \\
\hline \multicolumn{2}{|l|}{ LRV findings } \\
\hline Diameter at the AM portion (mm) & $1.69 \mathrm{~mm} \pm 0.70$ \\
\hline Diameter at the hilar portion $(\mathrm{mm})$ & $8.01 \mathrm{~mm} \pm 2.27$ \\
\hline Angle between SMA and LRV & $25.26 @ \pm 7.98$ \\
\hline \multicolumn{2}{|l|}{ Treatment, n(\%) } \\
\hline Conservative & $20(86.9 \%)$ \\
\hline Surgery & $3(13.0 \%)$ \\
\hline
\end{tabular}

Parameters compatible with normal distrubution were defined as meantstandard deviations. $L R V=L$ eft renal vein, $A M=$ Aortomesenteric, $S M A=S$ uperior mesenteric artery. patients' values were under $40^{\circ}$ (Table 1). Radiological images of one of the patients who underwent surgery were shown in figures. The length between the abdominal aorta and superior mesenteric artery was $44 \mathrm{~mm}$ (Figure 1a) and the length between the abdominal aorta and superior mesenteric artery was $17 \mathrm{~mm}$ (Figure 1b) before exercise. The aorta mesenteric angle was 28 degrees (Figure 2a) before exercise; 22 degrees (Figure $2 b$ ) after exercise.

A total of our twenty (82\%) patients responded to medical treatment. Medical treatment includes painkillers, exercise restriction, and posture correction.

\section{Surgical Procedures}

A total of three patients had refractory colic pain and proteinuria. There was no clinical or laboratory improvement despite exercise limitation and painkillers applied to other patients. Surgical treatment was applied to these three patients whose quality of life deteriorated and did not respond to medical treatment. The aim of the surgery should be to remove the pressure on the renal vein, protective vessel graft placement or venous transposition surgery was preferred.

Our 3 patients (18\%) who underwent surgery have serious recurrent colic flank pain and resistant proteinuria (especially 2 of them in 24-hour protein excretion). Left renal vein transposition has been done on two patients. We preferred the abdominal laparotomy approach for these patients. We have found and changed the position of the LRV relative to the SMA and aorta. The left renal vein, which was trapped between the aorta and SMA, was released by carefully sharp and blunt dissections and fixed more inferiorly. We did not need excision and anastomosis to the LRV. We checked the current in the LRV and ended the process.

A protective vessel graft was placed around the left renal vein of one of the patients and her CT angiography images were shown in Figure $1 a, b, c$, and Figure 2a,b. At the hilus level, the left renal vein diameter was measured as $70 \mathrm{~mm}$ at rest and $83 \mathrm{~mm}$ after exercise. The length between the abdominal aorta and superior mesenteric artery was $44 \mathrm{~mm}$ at rest and $17 \mathrm{~mm}$ after exercise. The aorta mesenteric angle was 28 degrees at rest and 22 degrees after exercise. The angle was too narrow and there was no clinical improvement with medical treatment. 


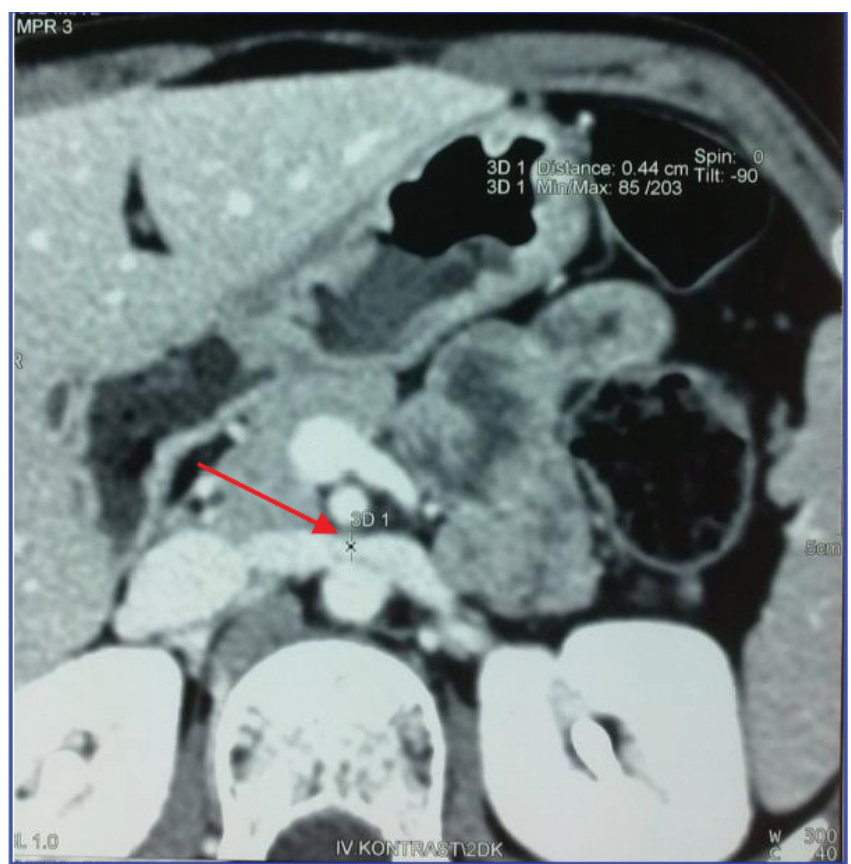

Figure 1a. Renal ven computed tomography angiography images before exercise, The length between abdominal aorta and superior mesenteric artery $(44 \mathrm{~mm})$ marked with a red arrow.

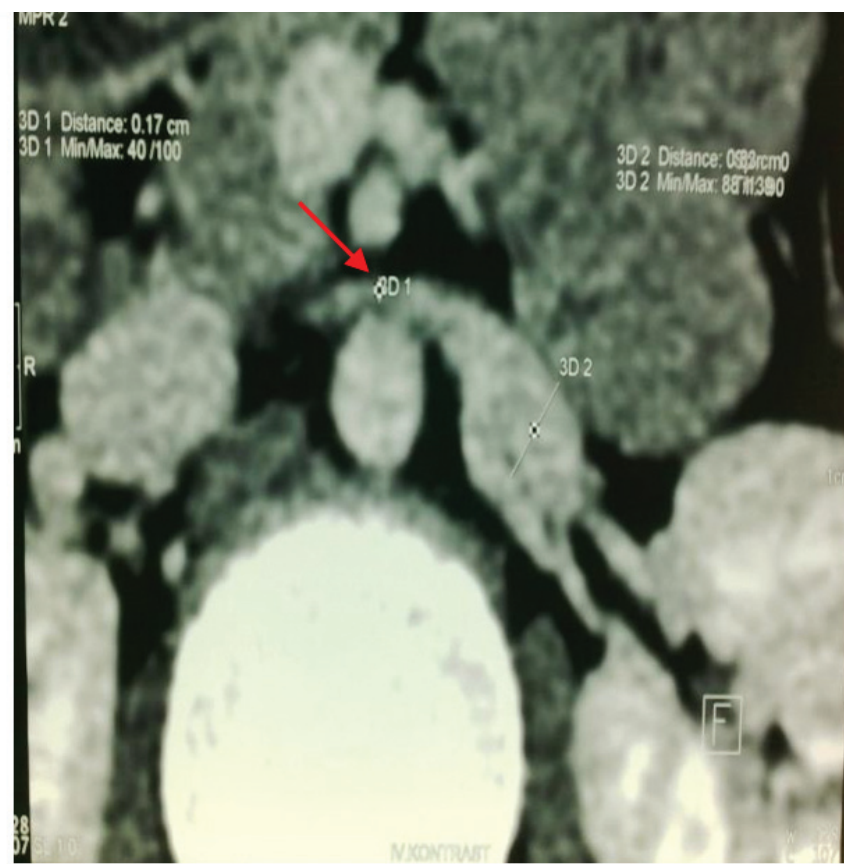

Figure 1b. Renal ven computed tomography angiography images after exercise, The length between abdominal aorta and superior mesenteric artery $(17 \mathrm{~mm})$ marked with a red arrow.

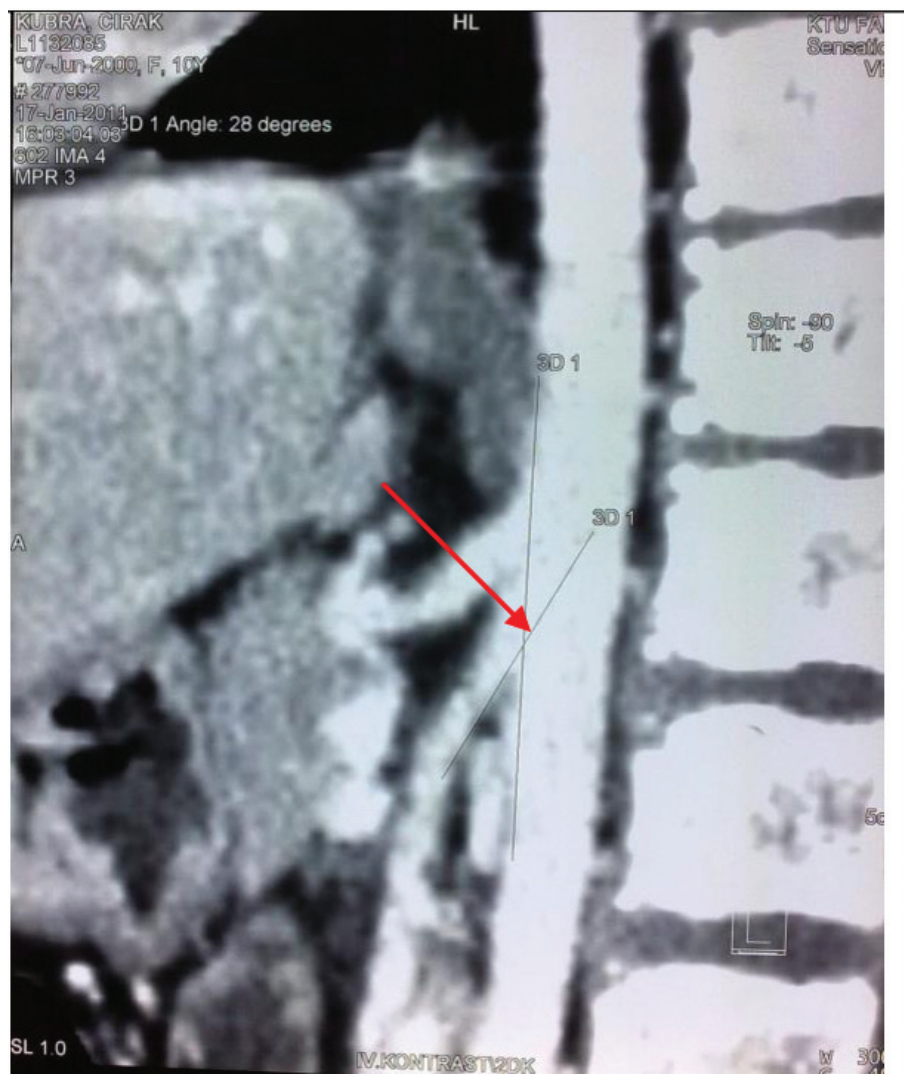

Figure 2a. Renal ven computed tomography angiography images before exercise, the aorta mesenteric angle was 28 degrees marked with a red arrow.

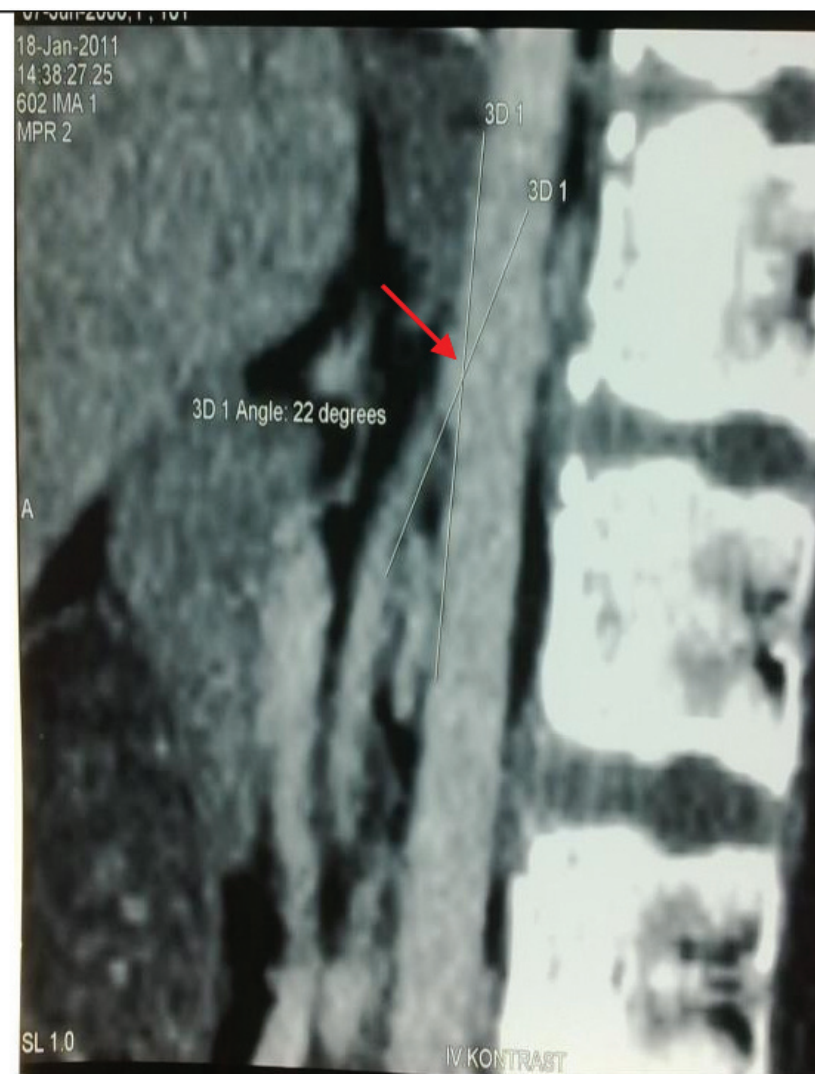

Renal ven computed tomography angiography images after exercise, the aorta mesenteric angle (22 degrees) marked with a red arrow. 
The patients, who did not repeat the complaints during the follow-up, was discharged following the urine microscopy. On the control examination, it was learned that the pain attacks and the microscopic hematurias did not recur.

\section{DISCUSSION}

Nutcracker syndrome (NCS) is a rare anatomicopathological condition defined as the compression of LRV between the abdominal aorta and the superior mesenteric artery ${ }^{(5,10)}$. Also, NCS is defining as anterior and posterior versions. Most variants of developmental LRV are the circumaortic and the retrocaval LRV. When the LRV is entrapping between the aorta and SMA called anterior NCS; whereas occurs between the vertebral column and the aorta called posterior NCS ${ }^{(1)}$. All patients in our study were anterior NCS. Physiologically, the angle between the superior mesenteric artery and the left renal vein is mostly between $35^{\circ}-40^{\circ}$. Nutcracker syndrome should be diagnosed when this angle decreases. All patients' angles were narrow. Diagnosis is made by ultrasonography, color flow Doppler ultrasonography, computed tomography angiography, or magnetic resonance angiography ${ }^{(5-8)}$. We first performed Doppler ultrasonography on our all patients and then were diagnosed with MRI and CT angiographies.

NCS is mostly seen in young and middle-aged ladies and usually presents ranging from asymptomatic to variable clinical symptoms like recurrent renal colic pain, micro or macroscopic hematuria, orthostatic proteinuria, and proteinuria attacks similar to our patients ${ }^{(2,6)}$. Her colic pains occurred after exercise. The pathology of hematuria is secondary to the rupture of septum separating veins because of increased left renal vein pressure and venous hypertension ${ }^{(6,11-13)}$. Our only 5 patients had no hematuria for any time. We showed orthostatic proteinuria in all our patients. 17 of our patients had mild, 3 had moderate and three others had severe proteinuria.

The management of NCS is based on the evaluation of the pathologic anatomy and physiology; and the treatment varies from a conservative approach to nephrectomy (progressive hematuria, proteinuria, and pain affecting daily life) depending on the patient's clinic and the severity of the disease ${ }^{(14)}$. Medical treatment(exercise restriction, painkillers, and posture correction), surgical, intravascular, or extravascular stent implantation, or intrapelvic chemical cautery are used in the treatment. In cases with NCS, major surgery is frequently performed in the form of renal retransposition, renal vein direct or graft reimplantation, medial nephropexy, left renal vein bypass, superior mesenteric artery (SMA) transposition, renal-toinferior vena cava shunt, and nephrectomy ${ }^{(7,11)}$.

Barnes et al. (15) first described extravascular stent in 1988. It is also an open surgery and some the complication may occur like in-stent stenosis, fracture, migration, or erosions. In the literature, some series preferred surgery as the first choice; however, conservativemedical treatment must be preferred at the first choice in childhood, as in our series ${ }^{(16)}$. Surgical treatment should be preferred in resistant cases because there is a risk of thrombosis and hypertension for these patients ${ }^{(17)}$. Surgical treatment was performed in our three patients who did not respond to the painkillers, exercise restriction, and posture correction. Patients had resistant proteinuria and the aorta mesenteric angles were too narrow especially after exercises. Specifically, the narrowed aortomesenteric angle was so important and it was a guide for surgery for us. The application of protective graft around the left renal vein has been done successfully in our one patient and clinical success was achieved. Left renal vein transposition was done on our other two patients. We think that surgery should not be avoided in patients with recurrent flank pain and laboratory findings who do not respond to medical therapy.

\section{CONCLUSION}

We recommend that in case of especially colic flank pain, proteinuria and hematuria NCS should keep in mind in the differential diagnosis. We finally suggest that surgical management may supply more enough clinic improvement when the patient has a response of medical therapy to prevent the risk of LRV thrombosis and hypertension.

Ethics Committee Approval: Karadeniz Teknik University Faculty of Medicine Scientific Research Ethics Committee approval was obtained (2019/359). 
Conflict of Interest: The authors declared that there were no conflicts of interest.

Funding: The authors received no specific funding for this work.

Informed Consent: Since our study was retrospective, consent was not obtained from the patients.

\section{REFERENCES}

1. Ahmed K, Sampath R, Khan MS. Current trends in the diagnosis and management of renal nutcracker syndrome: $A$ Review. Eur J Vasc Endovasc Surg. 2006;31(4):410-6. https://doi.org/10.1016/j.ejvs.2005.05.045

2. Reed NR, Karla M, Bower TC, Vrtiska TJ, Ricotta II JJ, Gloviczki P. Left renal vein transposition for nutcracker syndrome. J Vasc Surg. 2009;49(2):386-94. https://doi.org/10.1016/j.jvs.2008.09.051

3. Nickavar A. Nutcracker syndrome; a rare cause of hematuria. J Nephropathol. 2016;5(4):144-5. https://doi.org/10.15171/jnp.2016.27

4. Brant W. Ullery, Nathan K. Itoga, Matthew W. Mell, Stanford. Transposition of the left renal vein for the treatment of nutcracker syndrome in children: A short-term experience. Annals of Vascular Surgery. 2014;28(8):1938.e5-8. https://doi.org/10.1016/j.avsg.2014.07.022

5. Barbey F, Venetz JP, Calderari B, Nguyen QV, Meuwly JY. Orthostatic proteinuria and compression of the left renal vein (nutcracker syndrome). Presse Med. 2003;32(19):883-5.

6. Waseem M, Upadhyay R, Prosper G. The nutcracker syndrome: an underrecognized cause of hematuria. Eur J Pediatr. 2012;(8):1269-71. https://doi.org/10.1007/s00431-012-1761-1

7. Gorospe EC, Aigbe MO. Nutcracker syndrome: A rare cause of hematuria. Clinical Image The ScientificWorld Journal. 2006;30(6):745-6. https://doi.org/10.1100/tsw.2006.144

8. Hanna HE, Santella RN, Zawada ET Jr, Masterson TE. Nutcracker syndrome: an underdiagnosed cause for hematuria? South Dakota Journal of Medicine. 1997;50(12):429-36.

9. Barnes RW, Fleisher iii HL, Redman JF, Smith JW, Harshfield $\mathrm{DL}$, Ferris EJ. Mesoaortic compression of the left renal vein (the so called nutcracker syndrome): Repair by a new stenting procedure. J Vasc Surg. 1988;8(4):415-21. https://doi.org/10.1016/0741-5214(88)90104-8

10. Nalcacioglu H, Bilgici MC, Tekcan D, Genc G, Bostanci Y, Yakupoglu YK, Sarikaya S, Ozkaya O. Nutcracker Syndrome in Children: Role of Doppler Ultrasonographic Indices in Detecting the Pattern of Symptoms. Journal of Clinical Medicine. 2018;7:214. https://doi.org/10.3390/jcm7080214

11. Denchev B, Domuschieva E, Jelev G, Govedarski V, Zahariev T. Surgical Treatment of a Patient With Nutcracker Syndrome via Transposition of the Left Renal Vein. EJVES Short Reports. 2018;41:10e12. https://doi.org/10.1016/j.ejvssr.2018.09.003

12. Gulleroglu K, Gulleroglu B, Esra Baskin. Nutcracker syndrome. World J Nephrol. 2014;6;3(4):277-81. https://doi.org/10.5527/wjn.v3.i4.277

13. Ma Z, Liu X, Ning Y. Nutcracker phenomenon in combination with glomerular nephritis in isolated hematuria patients. Int Urol Nephrol. 2013;45:809-16. https://doi.org/10.1007/s11255-012-0265-2

14. Alaygut D, Bayram $M$, Soylu A, Cakmakcı H, Türkmen $M$, Kavukcu S. Clinical course of children with nutcracker syndrome. Urology. 2013;82(3):686-90. https://doi.org/10.1016/j.urology.2013.03.048

15. Shaha D, Qiub X, Shahb A, Cao D. Posterior nutcracker syndrome with left renal vein duplication: Anuncommon cause of hematuria. International Journal of Surgery Case Reports. 2013;4:1142-4. https://doi.org/10.1016/j.ijscr.2013.10.012

16. Ananthan K, Onida S, Davies AH. Nutcracker Syndrome: An Update on Current Diagnostic Criteria and Management Guidelines. Eur J Vasc Endovasc Surg. 2017;53(6):886-94. https://doi.org/10.1016/j.ejvs.2017.02.015

17. Erben $Y$, Gloviczki P, Kalra M, Bjarnason $H$, Reed NR, Duncan AA, Oderich GS, Bower TC. Treatment of nutcracker syndrome with open and endovascular interventions. J Vasc Surg Venous Lymphat Disord. 2015;3(4):389-96. https://doi.org/10.1016/j.jvsv.2015.04.003 